\title{
Morphological Variations of Human Spleen and its Clinical Significance
}

\author{
Chaudhari $\mathrm{ML}^{1}$, Maheria $\mathrm{PB}^{2}$, Lakhani $\mathrm{C}^{3}$, Menezes $\mathrm{VR}^{4}$ \\ ${ }^{1}$ Dr Manisha L chaudhari\#, Assistant professor, Department of Anatomy, ${ }^{2}$ Dr pankaj maheria, Assistant professor, \\ Department of Anatomy, GMRES Medical Collage, Dharpur, Patan, Gujarat, ${ }^{3}$ Dr Chintan lakhani ${ }^{\#}$, Assistant professor, \\ Department of Anatomy, ${ }^{4} \mathrm{Dr}$ Vandana Menezes ${ }^{\#}$, Tutor, Department of Anatomy, All ${ }^{\#}$ are affiliated with Gujarat Adani \\ institute of Medical Science, Bhuj-370001, Gujarat,India
}

Address for correspondence: Dr Manisha Chaudhari, Email: drmanishachaudhari6@gmail.com

\begin{abstract}
Introduction: The spleen is an important lymphatic organ in the human body. Its immunological and haematological functions are being well realized. Aim of the present study to compare morphological variations of spleen with other workers and try to correlate these variations with some important clinical conditions. Materials and Methods: The present study included 62 human cadaveric spleens. The morphological features of the spleen like its length, breadth, width and weight were measured. The shape, poles, borders, surfaces and the impressions on the spleen were observed. Results: The lengths of the spleens varied between $6 \mathrm{~cm}$ and $14 \mathrm{~cm}$, with an average length of $9.59 \mathrm{~cm}$. Their breadth was observed to vary between $3.5 \mathrm{~cm}$ and $8.5 \mathrm{~cm}$, with an average breadth of $6.58 \mathrm{~cm}$., widths of the spleens varied from $2 \mathrm{~cm}$ to $7 \mathrm{~cm}$, with an average width of $4.54 \mathrm{~cm}$. Various shapes of the spleens were observed in the present study. Out of 62 spleens tetrahedral shaped (33.87\%) was most common followed by wedge (32.25\%) and triangular (19.35\%) shape. In 50\% of the cases notches were found on the superior border. The number of notches varied from zero to five, but in most of the cases $(67.74 \%)$, there were 1 or 2 notches. Conclusion: The findings of the present study will be of fundamental importance to the physicians, surgeons and radiologists and gives clue for various clinical diseases.
\end{abstract}

Keywords: spleen notch, spleen, shape of spleen.

\section{Introduction}

In humans, the spleen is the largest lymphatic organ. It is connected to the blood vascular system. It consists of a large encapsulated mass of lymphoid and vascular tissues. It is situated in the left hypochondrium and partly in the epigastrium, between the fundus of the stomach and the diaphragm. The shape of the spleen varies from a slightly curved wedge to a domed tetrahedron ${ }^{1}$. The size and weight of the spleen vary with age ${ }^{1}$. In adults, it is usually $12 \mathrm{~cm}$ long, $7 \mathrm{~cm}$ broad and 3 to $4 \mathrm{~cm}$ wide. Its average adult weight is $150 \mathrm{gm}$, but the normal range is wide, between 80 and $300 \mathrm{gm}^{1,2}$. The spleen has two surfaces; superolateral or diaphragmatic and inferomedial or visceral. It has two poles, the anterior and the posterior and two borders, superior and inferior ${ }^{1,2,3}$. The diaphragmatic surface is convex and smooth. The visceral surface is irregular and it is marked by gastric, renal, colic and pancreatic impressions. The posterior pole usually faces the vertebral column. The anterior pole is broad and

Manuscript received: $24^{\text {th }}$ Dec 2013

Reviewed: $26^{\text {th }}$ Dec 2013

Author Corrected; $29^{\text {th }}$ Dec 2013

Accepted for Publication: 30 $0^{\text {th }}$ Jan 2014 it is directed laterally. On the superior border, near the anterior pole, there may be one or two notches, persisting from the lobulated form of the spleen in early foetal life.

Measurement of the splenic length in the routine clinical practice is a very good indicator of actual splenic size ${ }^{4}$. Splenomegaly is an important diagnostic clue to the existence of an underlying disorder ${ }^{5}$. The spleen is affected by number of disorders e.g. abnormalities of the cells that populate within the spleen like malaria, kalaazar etc $^{6}$, or disturbance of storage function of the spleen like sarcoidosis, leukaemia etc ${ }^{7}$. The spleen is lobulated in the fetus, but the lobules normally disappear before birth. The notches in the superior border of the adult spleen are remnants of the grooves that separated the fetal lobules ${ }^{8}$.

\section{Materials and Methods}

The present study was conducted in the anatomy departments of Adani Medical Collage, Bhuj. Study included 62 human adult cadaveric spleens. Apparently normal human cadaveric spleens of both the sexes were selected. Out of the 62 spleens, only 15 specimens of the 
spleen belonged to female cadavers. As only very less number of spleens of female cadavers were available, it was difficult to do a comparative study between the males and females. So, spleens from both sexes were added together and a statistical analysis was done, without considering the sexual dimorphism.

To remove the spleens from the abdominal cavity, they were detached from their various attachments and the splenic vessels were cut near the hilum after ligation. Dissection was done according to standard protocol ${ }^{9}$. They were washed with tap water to clean the debris and the fatty tissue. The shapes of all spleens were noted. They were weighed on an electronic weighing machine and their lengths, breadths and widths were measured. We considered the greatest distance between the two poles of the spleen as its length, the greatest distance between two points at the same level on the superior and inferior borders as its breadth and the greatest width as the width of the spleen. ${ }^{3}$ We measured these values with the help of spreading and sliding calipers. The borders, surfaces and poles of the spleen were determined.

The notches on the borders and the impressions on the surfaces of the spleen were observed carefully. The data which was thus obtained, was tabulated, statistically analyzed in Microsoft excel 2007 and compared with that of other studies. We remove damage spleen from study only anatomically sound spleen consider for study.

\section{Results}

In the present study, out of 62 spleens, 21 (33.87\%) were tetrahedral shaped, 20 (32.25\%) were wedge shaped, $12(19.35 \%)$ were triangularshaped, 5(8.06\%) were oval shaped and $4(6.45 \%)$ were irregular in shape.

Weight of 50(80.64\%) spleens was between 80 to $300 \mathrm{gm}$, with a maximum number i.e. $33(53.22 \%)$ of specimens with weights in the range of 80 to $150 \mathrm{gm}$ (Bar Chart 1)

\section{Bar Chart 1: Variations in the weight of spleen}

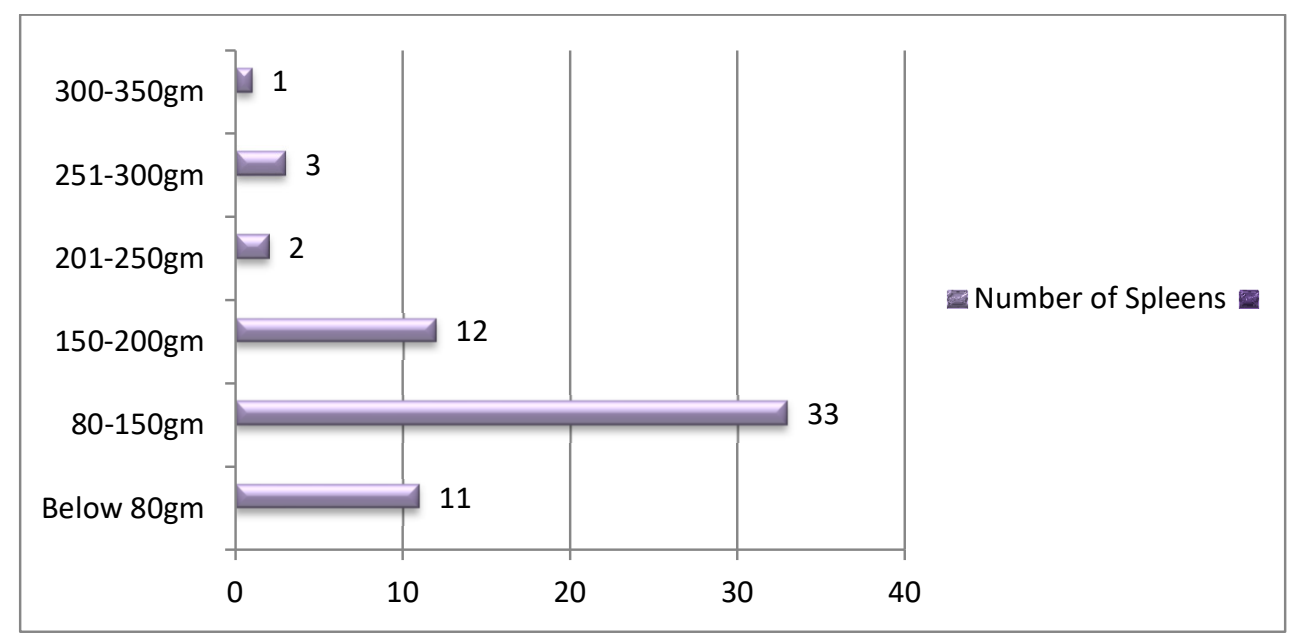

In the present study, the lengths of the spleens varied between $6 \mathrm{~cm}$ and $14 \mathrm{~cm}$, with an average length of $9.59 \mathrm{~cm}$. Most of the spleens were in the range of $08 \mathrm{~cm}$ to $12 \mathrm{~cm}$ in size (Table: 1)

\section{Table1: Variations in length of spleen}

\begin{tabular}{|l|l|l|}
\hline Length (cm) & No. of specimen & Percentage \\
\hline $\mathbf{6 - 8}$ & 15 & 24.19 \\
\hline $\mathbf{8 - 1 0}$ & 24 & 38.79 \\
\hline $\mathbf{1 0 - 1 2}$ & 19 & 30.64 \\
\hline$>\mathbf{1 2}$ & 4 & 6.45 \\
\hline
\end{tabular}

Their breadth was observed to vary between $3.5 \mathrm{~cm}$ and $8.5 \mathrm{~cm}$, with an average breadth of $6.58 \mathrm{~cm}$. Most of the spleens were in the range of $3.5 \mathrm{~cm}$ to $7.5 \mathrm{~cm}$ in size (Table: 2 ) 
Table 2: Variations in breadth of spleen

\begin{tabular}{|l|l|l|}
\hline Breadth $[\mathbf{c m}]$ & No. of specimen & Percentage \\
\hline $\mathbf{3 . 5 - 5 . 5}$ & 14 & 22.58 \\
\hline $\mathbf{5 . 5 - 7 . 5}$ & 36 & 58.06 \\
\hline $\mathbf{7 . 5 - 9 . 5}$ & 12 & 19.35 \\
\hline
\end{tabular}

It was found that the widths of the spleens varied from $2 \mathrm{~cm}$ to $7 \mathrm{~cm}$, with an average width of $4.54 \mathrm{~cm}$. In most of the cases spleens width was in the range of $2 \mathrm{~cm}$ to $6 \mathrm{~cm}$ (Table: 3 ).

Table: 3 Variations in width of spleen

\begin{tabular}{|l|l|l|}
\hline Width $[\mathrm{cm}]$ & No. of specimen & Percentage \\
\hline $2-4$ & 23 & 37.09 \\
\hline $4-6$ & 35 & 56.45 \\
\hline $6-8$ & 4 & 6.45 \\
\hline
\end{tabular}

In all the spleens two poles, two borders and two surfaces were observed. The diaphragmatic surface of the spleen showed a uniform morphology, while its visceral surface showed gastric, renal, colic and pancreatic impressions due to their pressure on the spleen.

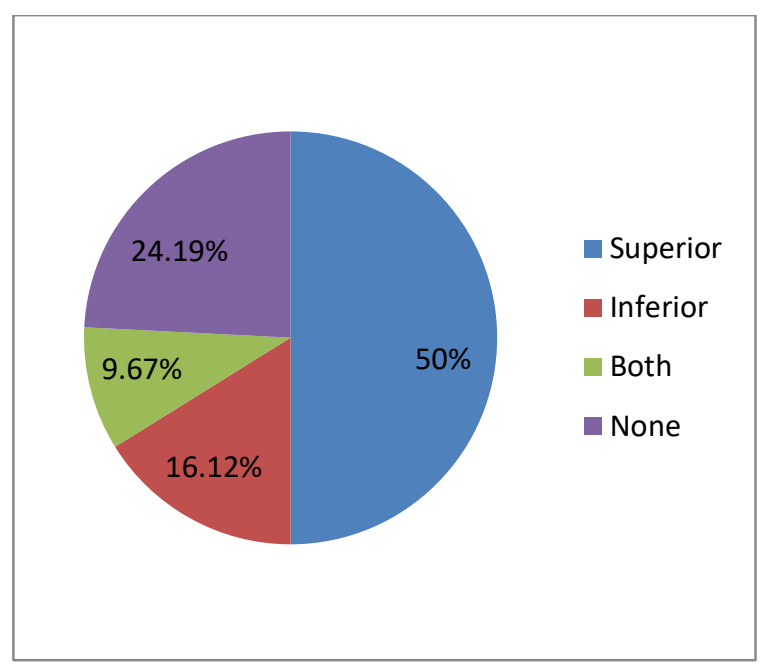

Chart 1: Border of spleen showing presence of notch

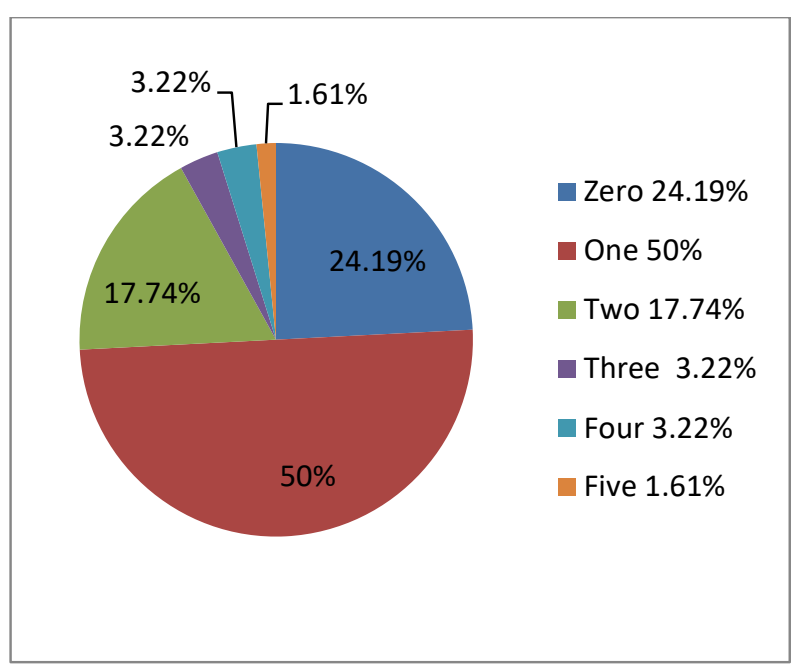

Chart 2: Number of notches observed on spleen

\section{Discussion}

The spleen is a mystery organ whose structural and functional relationships have started being realized only now. As reported by Michels ${ }^{3}$ and as mentioned in Gray's anatomy ${ }^{1}$ we have found so many variations in the morphology of the spleen.

The values for the length, breadth, width and weight of the spleen in the present study were slightly lower than those which were reported from previous studies. , $^{21,13}$

This may be due to the differences in the genetic factors, body constitution, geographical conditions, feeding habits and the better socioeconomic status, in the western countries where these studies were done. (Table 4,5$)$ 
Table 4: Variation in shapes of spleen

\begin{tabular}{|l|l|l|l|l|}
\hline Shape & Rao et $\mathrm{al}^{13}$ & Hollinshead $\mathrm{WH}^{2}$ & ${\text { Chaware et } \mathrm{al}^{11}}^{\text {Present study }}$ \\
\hline Wedge & $40 \%$ & $44 \%$ & $61.26 \%$ & $33.87 \%$ \\
\hline Triangular & $32 \%$ & $42 \%$ & $12.61 \%$ & $19.35 \%$ \\
\hline Tetrahedral & $20 \%$ & $14 \%$ & $21.62 \%$ & $32.25 \%$ \\
\hline Oval & $8 \%$ & - & $3.60 \%$ & $8.06 \%$ \\
\hline Iregular & - & - & $0.90 \%$ & $6.45 \%$ \\
\hline
\end{tabular}

Table 5: Variation in Length, Breadth \& Width

\begin{tabular}{|c|c|c|c|c|c|}
\hline Measurement & $\begin{array}{l}\text { Textbook of } \\
\text { grey anatomy }\end{array}$ & Michels NA ${ }^{3}$ & Rao et $\mathrm{al}^{13}$ & Chaware et al ${ }^{11}$ & Present study \\
\hline Length & 12 & 11 & 10.5 & 9.66 & 9.59 \\
\hline Breadth & 7 & 7 & 8.3 & 6.22 & 6.59 \\
\hline Width & 3 to 4 & 3 & - & 3.06 & 4.54 \\
\hline
\end{tabular}

In our study the weight varied between 80 and $350 \mathrm{gm},{ }^{2}$ except in $11.74 \%$ of the specimens, in which it was below 80 gm. The average adult weight of the spleen is $150 \mathrm{gm}$, which varies from 80 to $350 \mathrm{gm}^{1}$

The spleen develops from the mesoderm. During its development, different lobules are formed, which fuse with each other later on. The indication of the lobulation in adult spleen is its notched upper border ${ }^{12}$. Sometimes, this lobulated appearance may persist in the spleen. That is why we can get many notches on the spleen, which can be seen on the superior as well as on the inferior borders. In the present study, the splenic notches were found on the superior as well as on the inferior borders. The number of notches varied from zero to five, but commonly, there were only one or two notches.

\section{Conclusion}

Studies $^{14,15}$ related to morphometric analysis of spleen seem to be under reported and need to be carried out actively at various medical institutions/colleges for obtaining more concrete information. The implications of such projects are that it not only enhance the fundamental knowledge but also furnishes many insights on spleen's size clinical utility and significance.

\section{Funding: Nil}

\section{Conflict of interest: Nil}

\section{Permission from IRB: Yes}

\section{References}

1. Standring S: Gray's Anatomy: The Anatomical Basis of the Clinical Practice, 39th edition. Edinburg: Elsevier Churchill Livingstone, 2006; 1239-44.

2. Hollinshead WH. Anatomy for Surgeons. 3rd ed. vol-2. New York: Harper and Row, 1982; 436-45.

3. Michels NA. The variational anatomy of the spleen and the splenic artery. American Journal of Anatomy 1942; 70: 21-72.
4. Lamb PM, Lund A, Kanagasabay RR, Martin A, Webb JAW, Reznek RH. Spleen size: how well do linear ultrasound measurements correlate with three-dimensional CT volume assessments? Br J Radiol 2002; 75(895): 573-7.

5. Kumar V, Abbas AK, Fausto N. Aster JC. eds. Robbins and Cotran pathologic basis of disease. 8th ed. New Delhi: Saunders Elsevier; 2010. p. 632

6. Beauchamp RD, Holzman MD. Fafiam TC, Spleen. In: Townsend CM, Beauchamp RD. Evers BM, Mattox KL. eds. Sabiston Text book of surgery: The biological basis of modern surgical practice. Vol. 2 17th ed. Bangalore: Saunders Elsevier; 1994. p. 1679-1708.

7. Maier RV. Spleen. In: Mulholland MW, Lillemoe KD, Doherty GM, Maier RV, Upchurch GR Jr. eds. Greenfield's surgery: scientific principles and practice. 4th ed. Philadelphia: Lippincott Williams \& Wilkins; 2005 .

8. Keith L.Moore,T.v.n Persaud.The digestive system. The developing Human:Clinically oriented Embryology.Eighth Edition.New yourk.New delhi, Elsevier publication,2008;224. 
9. G.J.Romanes, The abdominal cavity, Cunningham manual of practical anatomy, fifteenth edition, New yourk,Oxford university press,2008;126-127.

10. Ungor B, Malas MA, Sulak O, Albay S. Development of spleen during the fetal period. Surg Radiol Anat. 2007;29(7):543-550

11. Charware PN, Belsare SM, Kulkarni YR, Pandit SV, Ughade JM. The Morphological Variations of the Human Spleen. Journal of Clinical and Diagnostic Research. 2012 April, Vol-6(2): 159-162
12. Sant S. Embryology for medical students. New Delhi: Jaypee brothers medical publishers (p) 1td., 2002; 203-04. 13. Rao S, Setty S, Katikireddi RS. Morphometric Study of Human Spleen. Int J Biol Med Res. 2013;

14. Skandalakis PN, Colborn GL, Skandalakis LJ, Richardson DD, Mitchell WE, Skandalakis JE. The surgical anatomy of the Spleen. Surg Clin North Am. 1993;73(4):747-68.

15. Soyluo lu AY, Tanyeli E,Marur T,Ertem AD, Ozku K, Akkyn SM. Splenic artery and relation between the tail of the pancrease and spleen in a surgical anatomy view. Karadeniz Typ Dergisi 1996;9:103-107.

\section{How to cite this article?}

Chaudhari ML, Maheria PB, lakhani C, Menezes VR. Morphological Variations of Human Spleen and its Clinical Significance. Int J Med Res Rev 2014;2(1):16-20, 10.17511/ijmrr.2014.i01.04 